Valentyna Frytsiuk,

PhD (Candidate of Pedagogical Sciences), associate professor, Department of Pedagogy and Professional Education, Mykhailo Kotsiubynsky State Pedagogical University of Vinnytsya, 32, Ostrozkoho Str., Vinnytsia, Ukraine

\title{
ASSESSMENT OF FUTURE TEACHERS' PREPAREDNESS FOR PROFESSIONAL SELF-DEVELOPMENT
}

The article presents the results of the assessment of the following components of future teachers' preparedness for professional self-development: motivational and axiological, informational and cognitive, organisational and activity, emotional and emotional and volitional, reflexive and evaluation. In order to assess the level of future teachers' preparedness for professional self-development the following methods were used: "Methods for assessing creative activity" by M. Rozhkov, Yu. Tiunnikov, B. Alishev, L. Volovich; "Test for assessing the level of sociability" by V. Riakhovskyi; "Self-confidence" by V. Romek; "Selfassessment of one's self-confidence" by S. Yemelianov; "Self-actualisation test", "Method of assessing volitional self-regulation" by A. Zverkov, Ye. Slidman; "Technique of self-evaluation and self-regulation" by S. Vershlovskyi; test "To what extent are you disciplined?" by L. Matsko, M. Pryschak, T. Pervunina; “Ability to self-management” by N. Peisakhov, etc. Some components were assessed by means of observation and expert evaluation. It has been found that before the experiment $6.19 \%$ of students from the experimental group (according to 3 criteria) had critical level of readiness for continuous professional self-development; $28 \%$ of the surveyed had adaptive level; $50 \%$ of the respondents has the basic level; $13.81 \%$ has the optimal one and 2,78 of the students had the creative level of preparedness. In the control group, $60.1 \%$ of the surveyed had critical level of preparedness for professional self-development; $25.96 \%$ - adaptive; $51.44 \%$ - basic; $14.42 \%$ - optimal and $2.16 \%$ - creative level of preparedness. Having considered the results of the experiment it has been concluded that it is reasonable to create conditions which would prepare students for professional self-development. Preparedness for professional self-development cannot be formed by means of direct pedagogical impact, because this ability cannot be transferred from a teacher to a student. However, a teacher can create the necessary conditions contributing the formation of the examined quality in students-future pedagogues.

Keywords: professional self-development, preparedness, readiness, future teachers, assessment, components.

Рецензент: д. пед. н., проф. О. В. Акимова

Подано до редакиіï 25.10.2016

УДК: $373.3+371.71+613.954-053$

Руслан Вікторович Бедрань, аспірант кафедри теорії і методики дошкільної освіти, Південноукраїнський національний педагогічний університет імені К. Д. Уиинського, вул. Старопортофранківська, 26, м. Одеса, Украӥна

\section{МЕТОДИКА ВИХОВАННЯ КУЛЬТУРИ ЗДОРОВ'Я ДІТЕЙ ДОШКІЛЬНОГО ВІКУ В РІЗНОВІКОВИХ ГРУПАХ}

У статті подано методику виховання культури здоров'я дітей дошкільного віку в різновікових групах, щзо описана як поетапна і послідовна реалізація визначених педагогічних умов і моделі відповідно до обраних етапів: когнітивно-збагачувального, репродуктивно-діяльнісного та емоційно-креативного. Схарактеризовано основні елементи виховної роботи на кожному етапі методики: тематичні заняття, ігрові ситуації, дидактичні, сюжетно-рольові, режисерські ігри, ігри-ситуаџї, проекти, скретч-проекти, ранкова гімнастика, гімнастика після денного сну, фізкультхвилинки, рухливі, музично-рухливі ігри, ритмічна гімнастика, фітболгімнастика, вправи на розвиток дихання, сили голосу, різні види вправ оздоровчої спрямованості, навчальноігрові ситуації, ігрові вправи культурно-оздоровчого спрямування, тематичні свята.

Ключові слова: методика, педагогічні умови, модель, етапи, основні елементи виховної роботи, культура здоров'я, діти різновікових груп.

При впровадженні експериментальної методики виховання культури здоров'я дітей старшого дошкільного віку у різновікових групах враховувалися структурні, динамічні та функціональні характеристики дитячої групи та особливості міжособистісних стосунків дошкільників, які зумовлюють психологіч- ний клімат та емоційне благополуччя дитини, що багато в чому визначає результативність виховних впливів. Відтак, у розробці експериментальної методики було враховано особливості групової структури та динамічні процеси у дитячих різновікових групах, провідні характеристики психологічного клімату та- 
кої дитячої групи задля розвитку групової згуртованості та співробітництва, колективізму та запобігання конфліктності між окремими дітьми та внутрішньогруповими об'єднаннями дошкільників. У зв'язку з цим робота в різновікових групах дошкільників вибудовувалася на засадах цілеспрямованості та умотивованості, прагненні до здійснення групових цілей та розвитку активного зацікавленого ставлення у спільній діяльності; цілісності та структурованості, взаємозв'язку всіх учасників групової діяльності та узгодженості дій учасників, спільному розподілі ролей та обов'язків у груповій діяльності; емоційного благополуччя та задоволеності міжособистісними стосунками та спілкуванням у групі; організованості та планомірності різних видів групової діяльності.

Метою статті є опис методики виховання культури здоров'я дітей дошкільного віку в різновікових групах.

Експериментальна методика виховання культури здоров'я дітей дошкільного віку в різновікових групах передбачала поетапну і послідовну реалізацію визначених педагогічних умов і моделі відповідно до обраних етапів.

Так, задля реалізації першої педагогічної умови наявність розвивального здоров'язбережувального середовища, спрямованого на виховання культури здоров'я дітей у різновікових групах - було створено «Центр здоров'я». Основними елементами виховної роботи в центрі були тематичні заняття, ігрові ситуації, дидактичні, сюжетно-рольові, режисерські ігри, ігри-ситуації, проекти, скретч-проекти тощо.

Створення «Центру здоров’я» відбувалося на першому - когнітивно-збагачувальному етапі - i мало на меті оволодіння дітьми, в межах цього центру, знаннями про здоров'я, здоровий спосіб життя, способами ведення здорового способу життя, розвитком цілеспрямованості, ініціативності та самостійності використання набутих знань у поведінці та діяльності для досягнення результатів із виховання культури здоров'я дітей відповідно до авторської програми «Виховуємо культуру здоров'я дітей дошкільного віку у різновікових групах (для дітей 5 та 6 року життя)».

Програма включала такі розділи: «Я, мій організм, моє здоров'я», «Соціальні умови здоров'я дитини», «Індивідуальне здоров’я дитини».

Усвідомлення дітьми змісту розділів програми систематизувалося за такими блоками:

- інформаційно-пізнавальний блок (що повинні знати діти 5-го року життя, та що повинні знати діти 6-го року життя);

оздоровчо-діяльнісний блок (що повинні вміти діти 5-го року життя, та що повинні вміти діти 6-го року життя);

- просвітницький блок (що повинні знати і вміти батьки дітей 5-го року життя, та що повинні знати і вміти батьки дітей 6-го року життя);
- методичний блок (як можна діяти вихователю в організації роботи 3 виховання дітей за даним питанням для дітей 5-го року життя та 6-го року життя).

Наводимо приклад розробки за цими блоками змісту до розділу «Я, мій організм, моє здоров'я»:

1) інформаційно-пізнавальний блок, що включає теоретичні відомості із запланованих тем.

У результаті засвоєння цього блоку діти 5-го ро$\kappa у$ життя повинні мати елементарні уявлення про:

- основні частини свого тіла (голову, шию, тулуб, кінцівки), знати їх призначення та дії;

- назви органів (серце, легені, шлунок, кишечник, печінка, нирки) і систем свого організму (серцево-судинної, дихальної, опорно-рухової, видільної, крові, шкіри);

основні прояви органів: око - бачить, вухо чує, ніс - відчуває запах, язик - смак, шкіра - температуру;

- основні суб'єктивні ознаки свого здоров'я (гарне самопочуття, апетит, настрій, бажання грати), об'єктивні ознаки свого здоров'я (зріст, маса тіла, температура тіла, відсутність болю);

- значення для зміцнення здоров'я загартовування, щоденної ранкової зарядки, масажу, правильного харчування, поведінки;

- основні ознаки нездоров'я (поганий апетит, висока температура, млявість, дратівливість чи примхливість);

- елементарні правила гігієни обличчя, рук, ніг, нігтів, волосся, вух, ротової порожнини, органів виділення;

роль лікаря у профілактиці захворювань, розуміння дотримання порад лікаря.

У результаті засвоєння цього блоку діти 6-го ро$\kappa y$ життя повинні мати елементарні уявлення про:

- будову свого тіла та правила гігієни за його доглядом, особливості належності до певної статі;

- органи (серце, легені, шлунок, кишечник, печінка, нирки) і системи свого організму (серцевосудинної, дихальної, опорно-рухової, видільної, крові, шкіри), про їх призначення;

- прояви органів: око - бачить, вухо - чує, ніс відчуває запах, язик - смак, шкіра - температуру; умовами догляду за органами;

- суб'єктивні ознаки свого здоров'я (гарне самопочуття, апетит, настрій, бажання грати), об'єктивні ознаки свого здоров'я (зріст, маса тіла, температура тіла, відсутність болю) та цінність здоров'я для людини;

- значення для зміцнення здоров'я загартовування, щоденної ранкової зарядки, масажу, правильного харчування, поведінки. Дитина вміє виконувати вправи, застосовувати здобуті знання, вміння та навички щодо збереження здоров'я;

- ознаки нездоров'я (поганий апетит, висока температура, млявість, дратівливість чи примхливість), їх вплив на власне здоров'я; 
- правила гігієни обличчя, рук, ніг, нігтів, волосся, вух, ротової порожнини, органів виділення, правила догляду за ними;

- роль лікаря у профілактиці захворювань, виконання порад лікаря.

2) оздоровчо-діяльнісний блок (знайомство дітей 3 комплексом вправ ранкової гігієнічної гімнастики (зарядки), щоденне проведення ранкової зарядки, проведення фізкультхвилинок, ведення щоденника спостереження за власним станом здоров'я, оформлення «Картки здоров'я»).

У результаті засвоєння цього блоку діти 5-го року життя повинні вміти й володіти навичками:

- щоденного чищення зубів (2 рази на день), умивати обличчя, шию, вуха, мити руки перед їжею після прийняття їжі, після туалету;

визначення індивідуального рівня свого здоров’я («Картка здоров'я») за допомогою батьків i медичної сестри.

У результаті засвоєння цього блоку діти 6-го року життя повинні вміти й володіти навичками:

- щоденного чищення зубів (2 рази на день), умивати обличчя, шию, вуха, мити руки перед їжею і після прийняття їжі, після туалету без нагадування 3 боку дорослих;

- ведення щоденника спостережень за власним станом здоров'я;

- за зовнішніми ознаками визначати стан здоров'я своїх товаришів;

- визначення індивідуального рівня свого здоров’я («Картка здоров’я») без сторонньої допомоги.

3) просвітницький блок (робота з батьками). У межах цього блоку батьків дітей 5-го та 6-го років життя:

- ознайомлюють 3 чинниками здоров'я, 3 комплексом вправ ранкової фізичної зарядки, харчування, стосунків у сім’ї і підключення їх у допомогу дітям;

- підключають до визначення індивідуального рівня здоров'я дітей і оформлення «Картки здоров'я».

4) методичний блок (на допомогу вихователям): розробка дидактичних, сюжетно-рольових, режисерських ігор, що сприяють формуванню в дошкільників уявлень, умінь і навичок за змістом кожного розділу для дітей 5го року життя та дітей 6-го року життя відповідно.

У Центрі розміщувалися дидактичні ігри різного змісту, що розкривали елементи культури здоров'я та основ здорового способу життя. Було представлено такі дидактичні ігри: «Режим дня», «Відгадай-ка», «Що шкідливо, що корисно», «Здорові зуби», «Склади чоловічка», «Одягнися на прогулянку», «Безпечно - небезпечно» та інші. Також у «Центрі здоров'я» розташовувалися матеріали для ігрових вправ, які дитина здатна виконати сама або спільно з однолітком (матеріали для розвитку зору, слуху тощо). Запропоновані дидактичні ігри та матеріали діти могли взяти додому для спільної діяльності з батьками. Це робилося з метою націлити дітей на те, що вони будуть «вчителями» і будуть підказувати батькам, що потрібно робити згід- но зі змістом обраної гри. Відповідність дошкільника позиції «вчителя» реалізує потребу дитини бути дорослим (О. Запорожець, Д. Ельконін). Цей прийом використовували після проведення пізнавальних занять. Це дозволяло закріплювати отримані в дитячому навчальному закладі знання, залучати батьків до проблеми ведення здорового способу життя, знайомити їх із способами ведення здорового способу життя.

3 метою закріплення у дітей способів діяльності вихователями розроблялися алгоритми, які містилися в тій частині групової кімнати, з якою було пов'язано здійснення цих способів дій: алгоритм миття рук - в умивальній кімнаті; послідовність виконання вправ - в руховому центрі; послідовність вправ для очей - у навчальній частині приміщення. Після того як у дітей зростав рівень самостійності і вони більше не потребувати нагадувань 3 боку вихователя і зорових вказівок, алгоритм діяльності розташовувався в «Центрі здоров'я», де діти могли розглядати його за мірою необхідності.

Отже, створення у навчальному дошкільному закладі здоров'язбережувального середовища, а саме «Центру здоров'я», забезпечило засвоєння дітьми 5-го та 6-го років життя основ культури здоров'я, розуміння необхідності ведення здорового способу життя, а також оволодіння доступними для дитини способами і вправами його ведення. Діти стали активніше в своїх проявах, 3'явилася потреба реалізовувати отримані знання в поведінці та самостійній діяльності, вони отримувати особистісно-значущий результат від цього процесу, що, в свою чергу, було показником наявності прагнення до культури здоров'я та ведення здорового способу життя.

Реалізація другої педагогічної умови - наповнення фізичного виховання дітей різновікової групи здоров'язбережувальним змістом 3 урахуванням їхніх вікових особливостей - відбувалася на репродуктивно-діяльнісному етапі роботи.

Організація вихователем фізкультурної діяльності та наповнення фізичного виховання необхідним здоров'язбережувальним змістом надавали дитині можливість уточнити і закріпити уявлення про елементи культури здоров'я та здорового способу життя, набути нових знань про важливість ведення здорового способу життя для збереження i зміцнення свого здоров'я, а також вправлятися в реалізації цих знань і уявлень у діяльності та поведінці. Основними формами роботи на цьому етапі виступили ранкова гімнастика, гімнастика після денного сну, фізкультхвилинки, рухливі, музичнорухливі ігри, ритмічна гімнастика, фітболгімнастика, вправи на розвиток дихання, сили голосу, різні види вправ оздоровчої спрямованості.

Так, наприклад, проведення ранкової гімнастики сприяло поглибленню дихання, посиленню кровообігу, обміну речовин, розвитку різних груп м'язів, правильній поставі, розгальмовуванню нервової системи після сну, викликала позитивні емо- 
ції. Під час виконання вправ обмежували кількість повторів для дітей 5-го року життя (6-8 разів, стрибки - до 16 разів), тоді як для дітей 6-го року життя кількість повторів складала 8-10 разів, стрибки 20-24 рази. Для того, щоб діти 6-го року життя могли виконати вправи більшу кількість разів, вони розпочинали виконання вправ першими, показували дітям 5-го року життя, як правильно їх робити, потім цю саму вправу виконували діти 5-го року життя. Якщо вправи були складні (розроблені лише для дітей 6-го року життя), їх виконували після того, як діти 5-го року життя йшли умиватися.

Гімнастика після денного сну містила у своєму складі загально- розвивальні вправи на різні м'язові групи зі зміною вихідних положень та спеціальні вправи для формування стопи й постави. Тривалість проведення гімнастичного комплексу тривала до 6 хв. для дітей 5-го року життя та до 9 хв. - для дітей 6-го року життя. Вимоги до проведення гімнастики після денного сну 3 дітьми були такими самими, як і до ранкової гімнастики.

Фізкультхвилинки проводилися під час організованих занять у вигляді короткотривалих комплексів фізичних вправ, що давало можливість зменшити втомлюваність дітей і відновити їхню працездатність для подальшої успішної роботи. До комплексів фізкультурних хвилинок входили 3-4 вправи, кожна 3 яких повторювалася 4-6 разів.

Наповненню здоров'язбережувальним змістом підлягали і підібрані рухливі, музично-рухливі ігри, вправи на розвиток дихання, сили голосу та різні види вправ за темами авторської програми «Виховуємо культуру здоров'я дітей дошкільного віку у різновікових групах (для дітей 5 та 6 року життя)», що відбивали елементи культури здоров'я та здорового способу життя дітей.

Під час проведення ігор та вправ у дітей уточнювалися знання про будову людського тіла, про призначення і функції органів чуттів і частин тіла, про розвиток органів почуттів, про дії, спрямовані на дбайливе ставлення до свого організму; формувалися уявлення про необхідність виконання правил особистої гігієни, про предмети особистого користування, про необхідність підбирати одяг по сезону тощо.

Запорукою міцного здоров'я є належний розвиток грудної клітини та повноцінного дихання. Основні шляхи, що ведуть до розвитку повноцінного дихання, такі: вправи з бігу, гімнастика дихальних м'язів, навчання правильного дихання, правильна постановка співу.

Мета профілактичних вправ верхніх дихальних шляхів полягала у тому, щоб навчити дітей дихати носом, підготувати до виконання складніших дихальних вправ. Вправи на розвиток дихання проводилися з обома підгрупами.

Отже, наповнення здоров'язбережувальним змістом фізичного виховання дітей різновікової групи 3 урахуванням їхніх вікових особливостей забезпечило можливість формування життєвих навичок, що сприяли збереженню здоров'я дітей i були основою для виховання культури здоров'я дітей дошкільного віку в різновікових групах.

На емоційно-креативному етапі була реалізована третя педагогічна умова - стимулювання взаємодії дітей різного віку в навчально-виховному процесі різновікової групи. Реалізація цієї умови передбачала попередню організацію вихователем педагогічної взаємодії із дітьми між собою. Педагогічна взаємодія з боку вихователя складалася із сукупності педагогічних рішень, які вихователь приймав у кожному конкретному сюжеті взаємодії, що мав свою конкретну мету. За Є. Герасимовою, цей алгоритм складається 3 шести етапів [1, с. 215-221]. Перший етап - визначення мети взаємодії, яка за необхідністю розпадається на мету власне педагогічну, усвідомлювану вихователем, і яка лежить в площині педагогічної діяльності, i на мету взаємодії, що лежить в площині предметної дитячої діяльності. Мета педагогічна, як правило, виходить із спектру завдань, окреслених вище, друга мета визначається змістом дитячої діяльності. У свою чергу обидві мети повинні бути конкретизованими стосовно дітей 5-го та 6-го років життя, учасників взаємодії. Тобто, організовуючи взаємодію дітей 5-го та 6-го років життя у процесі ігрової діяльності, вихователь визначав мету - розвиток у дітей соціально цінних способів взаємодії. Стосовно дітей 5-го року життя ця мета конкретизована так - розвиток уміння приймати тільки необхідну допомогу старшої дитини. Стосовно дітей 6-го року життя мета уточнюється в такий спосіб - розвиток уміння пропонувати і надавати молодшій дитині тільки необхідну дозовану допомогу. Цілі, які лежать в площині конкретної діяльності, визначаються рівнем засвоєння цієї діяльності кожною дитиною і перспективою іï розвитку в певному віці певної дитини. Другий етап - складання композицій дітей, що взаємодіють (підбір за рівнем і особливостями розвитку, типу соціальної активності, наявності особистісних симпатій і антипатій, статі тощо). Третій - вибір об'єкта (молодша, старша дитина або сама діяльність) первинного впливу, що включає систему взаємодій. Цей етап наче закладає педагогічно доцільні акценти: або взаємодія розгортається від молодшого (акцент зміщений у бік інтересів, умінь, проблем молодшого партнера, старший сприяє, його діяльність підпорядкована діяльності молодшого), або від старшого партнера (тоді молодший надає посильну допомогу, його діяльність підпорядкована старшому). Четвертий етап - в ході взаємодії - відстеження динаміки взаємних дій і взаємних впливів дітей. Слід ураховувати виявлену тенденцію освоєння способів взаємодії з партнером іншого віку: у молодших дітей розвиток йде від переважання підпорядкування до зростання ініціативи (підтягування до старшого), у старших - від переважання ініціативи до зростання підпорядкування («підігрування» молодшому). П'ятий етап - взаємодія 3 дітьми під час діяльності. Виходячи 3 визнання значного розвиваючого 
потенціалу міжвікової дитячої взаємодії, що виникає iз соціально-психологічних особливостей, цей етап включається тільки в мінімальному ступені за крайньої необхідності (конфлікт, не будь-який, а гострий, що загрожує застосуванням сили, загрози здоров'ю дитини). Якщо чітко і грамотно пройдені всі попередні етапи, п'ятий в діяльності вихователя не представлений зовсім або значно згорнуто. Шостий етап фіксація і оцінка результату взаємодії, розгорнутих в трьох взаємопов'язаних площинах:

- об’єктивно-предметний результат - площина дитячої діяльності (якого результату в діяльності діти домоглися: молодша, старша, обидві разом);

- суб'єктивно-психологічний - площина дитячого розвитку (як позначився цей результат і процес взаємодії на розвиток дітей);

- суб'єктивно-психологічний - площина педагогічної рефлексії (аналіз вихователем власної діяльності 3 позицій взаємодії з дітьми під час їхньої взаємодії один з одним і свого розуміння всієї системи взаємодії).

Ігрові взаємодії дітей різновікових груп вимагають такого сценарію педагогічної взаємодії, як етап попередньої «змови» вихователя зі старшою дитиною 3 приводу майбутньої гри 3 молодшою. Вихователь створює позитивну мотивацію у старшої дитини, ставить конкретне завдання перед нею. Промовляє можливі варіанти дій старшої дитини 3 іiі участю допомагає їй визначити можливі способи впливу на гру молодшої. Способи впливу старшого партнера на гру молодшого можуть бути такими:

- показ ігрової дії;

- підказка сюжетного ходу ігрової дії, використання грального обладнання;

- пояснення правил гри, як використовувати ігрові предмети і т.ін.;

- спільна ігрова дія;

- розвиток рольового діалогу;

\section{ЛIТЕРАТУРА}

1. Герасимова Е.Н. Педагогические основы построения образовательного процесса в разновозрастной группе детского сада : дисс. ... доктора пед. на-

\section{REFERENCES}

1. Gerasimova, E. N. (2002). Pedagogicheskie osnovy postroeniya obrazovatelnogo protsessa v raznovozrastnoy gruppe detskogo sada [Pedagogical bases of the de-

- взяття старшим на себе ролі об'єкта ігрових дій молодшої дитини (дочки в грі «дочки-матері»);

- вербальне позначення рольової зв'язки («я мама, ти - синок»);

- опосередкований вплив на ігрові дії малюка;

- взяття на себе провідної ролі (демонстрація зразка).

При використанні цих прийомів важливо було, щоб старші не пригнічували ігрової активності молодших і не починали грати замість них. Усі перераховані варіанти взаємодії старшої дитини з молодшою в грі були можливі за рахунок активної позиції старшої дитини як суб'єкта ігрової діяльності, що дозволяла дитині бути одночасно і в грі, і над грою, бачити i усвідомлювати свою власну позицію в ігровій діяльності та позицію молодшої дитини.

Стимулювання взаємодії дітей різного віку в навчально-виховному процесі відбувалася у навчальноігрових ситуаціях: «Я і моє тіло», «Пізнай своє тіло», «Органи людини», «Наші помічники - органи чуття», «Чому болять зуби?», «Здорові зуби - гарний настрій», «Мікроби шкодять здоров'ю», «Для чого потрібно мити руки», «Уроки доктора Айболіта», «Ой, ти, дівчинкабруднуля», «Де Тімоша здоров'я своє шукав?», «Як наше тіло отримує енергію?», «Повітря, сонце і вода - в нас здорова дітвора», «Як працює наше серце»; ігрових вправах культурно-оздоровчого спрямування «Особиста гігієна», «Треба, треба вмиватися вранці та ввечері», «Грязнулі», «Катя і Антон», «Пізнай своє тіло», «Лікарня», «Подорож в країну Нехворійка»; тематичних святах «День здоров'я», «Подорож на планету Здоров'я», «Спортландія», «За здоровий спосіб життя» тощо.

Позитивні зміни у дітей в експериментальних групах після завершення формувального експерименту підтвердили ефективність запропонованих педагогічних умов, моделі й експериментальної методики виховання культури здоров'я дітей дошкільного віку в різновікових групах.

ук : 13.00.07 / Герасимова Евгения Николаевна. СПб., 2002. -339 с.

velopment of the educational process in the group of preschool children of different age]. Candidate's thesis. Saint Petersburg [in Russian].

Руслан Викторович Бедрань, аспирант кафедры теории и методики дочкольного образования, Южноукраинский национальный педагогический университет имени К. Д. Ушинского, ул. Старопортофранковская, 26, г. Одесса, Украина

\section{МЕТОДИКА ВОСПИТАНИЯ КУЛЬТУРЫ ЗДОРОВЬЯ ДЕТЕЙ ДОШКОЛЬНОГО ВОЗРАСТА В РАЗНОВОЗРАСТНЫХ ГРУППАХ}

В статье представлена экспериментальная методика воспитания культуры здоровья детей дошкольного возраста в разновозрастных группах, которая предусматривала поэтапную и последовательную реализацию выделенных педагогических условий и модели в соответствии с выбранными этапами: когнитивно-обогатительного, репродук- 
тивно-деятельностного и емоционально-креативного. Так, для реализации первого педагогического условия - наличия развивающей здоровьясберегающей среды, направленной на воспитание культуры здоровья детей в разновозрастных группах, был создан «Центр здоровья». Основными элементами воспитательной работы в центре были тематические занятия, игровые ситуации, дидактические, сюжетно-ролевые, режиссерские игры, игры-ситуации, проекты, скретч-проекты. Создание «Центра здоровья» происходило на первом - когнитивно-обогатительном этапе. В рамках этого центра дети получали знаниями о здоровье, здоровом образе жизни, о способах ведения здорового образа жизни. У детей развивали целеустремленность, инициативность и самостоятельность в использовании приобретенных знаний в поведении и деятельности для достижения результатов по воспитанию культуры здоровья детей в соответствии с авторской программой «Воспитываем культуру здоровья детей дошкольного возраста в разновозрастных группах (для детей 5 и 6 года жизни)». Реализация второго педагогического условия - наполнение физического воспитания детей разновозрастной группы здоровьясберегающим содержанием с учетом их возрастных особенностей - происходила на репродуктивно-деятельностном этапе работы. Организация воспитателем физкультурной деятельности и наполнение физического воспитания необходимым здоровьясберегающим содержанием давали ребенку возможность уточнить и закрепить представление об элементах культуры здоровья и здорового образа жизни, помогали приобрести новые знания о важности ведения здорового образа жизни для сохранения и укрепления своего здоровья, а также упражняться в реализации этих знаний и представлений в деятельности и поведении. Основными формами работы на данном этапе выступили: утренняя гимнастика, гимнастика после дневного сна, физкультминутки, подвижные, музыкально-подвижные игры, ритмическая гимнастика, фитбол-гимнастика, упражнения на развитие дыхания, силы голоса, различные виды упражнений оздоровительной направленности. На эмоционально-креативном этапе было реализовано третье педагогическое условие - стимулирование взаимодействия детей разного возраста в учебно-воспитательном процессе разновозрастной группы. Реализация этого условия предусматривала предварительную организацию воспитателем педагогического взаимодействия с взаимодействующими между собой детьми. Стимулирование взаимодействия детей разного возраста в учебно-воспитательном процессе проходило в учебно-игровых ситуациях, игровых упражнениях культурно-оздоровительного направления, тематических праздниках и т.п. Положительные изменения у детей в экспериментальных группах после завершения формирующего эксперимента подтвердили эффективность предложенных педагогических условий, модели и экспериментальной методики воспитания культуры здоровья детей дошкольного возраста в разновозрастных группах.

Ключевые слова: методика, педагогические условия, модель, этапы, основные элементы воспитательной работы, культура здоровья, дети разновозрастной группы.

\section{Ruslan Bedran, post-graduate student, Department of Theory and Methods of Preschool education, South Ukrainian National Pedagogical University named after K. D. Ushynsky, 26, Staroportofrankivska Str., Odesa, Ukraine}

\section{TECHNIQUE OF HEALTH CULTURE EDUCATION OF PRESCHOOL CHILDREN IN DIFFERENT AGE GROUPS}

The article deals with the experimental technique of health culture education of preschool children in different age groups, which involved staged sequential implementation of the pedagogical conditions according to the following stages: cognitive, reproductive and emotional. In order to implement the first pedagogical condition (the availability of the developmental health-saving environment, focused on the health culture education), the "Health Centre" has been created. The educational work in the centre involved role playing, different games, and projects. The creation of the centre was carried out at the cognitive stage. Children acquired knowledge about their health, organism, healthy lifestyle, etc. Such traits as purposefulness, leadership and independence in using the obtained knowledge have been developed in preschoolers. The implementation of the second pedagogical conditions (implementing health-saving elements into the physical education process) was carried out at the reproductive stage. This stage involved morning exercises, gymnastics, active games, fitball exercises, etc. At the emotional stage, the third pedagogical condition (stimulating the interaction of the preschool children of different age) was implemented. This condition provided organisation of the pedagogical interaction between all preschoolers of different age. This stage involved the following methods of work: study and game situations, recreational gymnastics, thematic parties, etc. The observed positive changes in the experimental groups of preschool children of different age after the completion of the experiment prove the efficiency of the suggested pedagogical conditions and the experimental technique of health culture education of preschool children in different age groups.

Keywords: technique, pedagogical conditions, model, stages, main elements of the educational work, health culture, children of different age.

Рецензент: д. пед. н., проф. В. В. Нестеренко

Подано до редакиіії 25.10.2016 